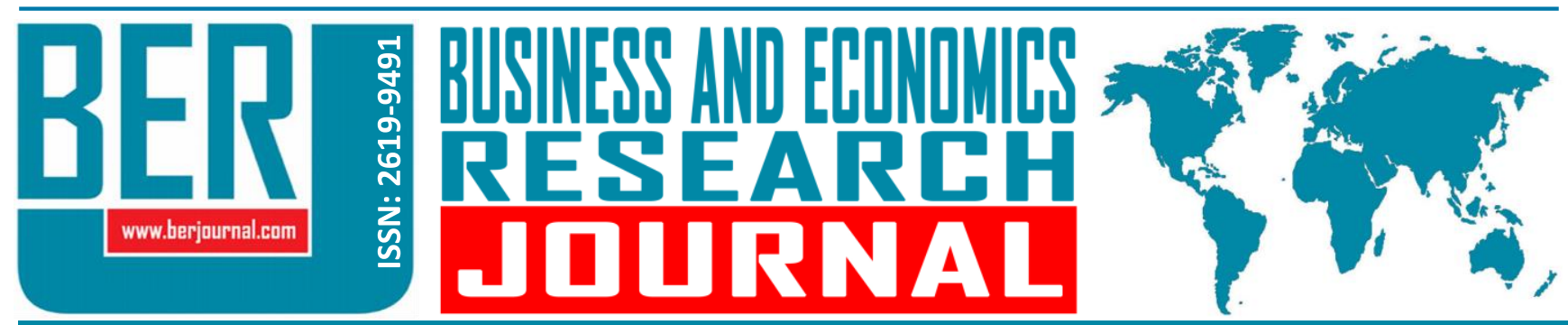

Business and Economics Research Journal Vol. 11, No. 2, 2020, pp. 531-543 doi: 10.20409/berj.2020.265

\title{
Örgütsel Özdeşleşmenin Bilgi Paylaşma Davranışı Üzerindeki Etkisi: Özgeciliğin Aracılık Rolü
}

\author{
Oguz Demirel ${ }^{\mathrm{a}}$, Onder Ulu
}

Öz: Bilgi örgütlerin hedeflerine ulaşması için olmazsa olmaz unsurların başında gelmektedir. Örgütün bilgi birikiminin artmasının yollarından biri de çalışanların sahip oldukları bilgiyi iş arkadaşlarıyla paylaşmalarıdır. Diğer bir deyişle bilgi paylaşma davranışı, örgütsel bilginin arttırılmasında kritik önemi haizdir. Bu nedenle, çalışanların bilgi paylaşma davranışının ardında yatan etmenleri araştırmak önem taşımaktadır. Bu çalışmanın amacı, örgütsel özdeşleşmenin bilgi paylaşma davranışı üzerindeki etkisini ve özgeciliğin bu etkideki aracılık rolünü sınamaktır. Araştırma, Düzce Üniversitesi'nde görev yapan akademik ve idari personel üzerinde gerçekleştirilmiştir. 345 adet anketten oluşan veri seti PROCESS eklentisi kullanılarak en küçük kareler regresyon tekniği ile analiz edilmiştir. Araştırma bulgularına göre, özgecilik, örgütsel özdeşleşme ve bilgi paylaşma davranışı arasındaki ilişkide "kısmi aracılık" etkisi göstermektedir. Araştırma sonunda araştırmacılara ve uygulamaya dönük bazı öneriler de sunulmuştur.

\section{The Effect of Organizational Identification on Knowledge Sharing Behavior: The Mediating Role of Altruism}

\begin{abstract}
Knowledge is one of the indispensable elements for organizations to achieve their goals. One of the ways to increase the knowledge of the organization is to share the knowledge of the employees with their colleagues. In other words, knowledge sharing behavior is critical in increasing organizational knowledge. For this reason, it is important to investigate the factors behind the knowledge sharing behavior of the employees. The aim of this study is to test the effect of organizational identification on knowledge sharing behavior and the mediating role of altruism in this effect. The research was carried out on academic and administrative staff working at Düzce University. The data set consisting of 345 questionnaires was analyzed with the least squares regression technique using the PROCESS plugin. According to the research findings, altruism shows "partial mediation" effect in the relationship between organizational identification and knowledge sharing behavior. At the end of the study, some suggestions for researchers and practice were also presented.
\end{abstract}

Anahtar Sözcükler: Örgütse Özdeşleşme, Bilgi Paylaşma, Özgecilik

JEL: M10, M19

$\begin{array}{ll}\text { Geliş } & : 13 \text { Ocak } 2020 \\ \text { Düzeltme } & : 28 \text { Şubat } 2020 \\ \text { Kabul } & : 23 \text { Mart 2020 } \\ \text { Tür } & : \text { Araştırma }\end{array}$

Keywords: Organizational Identification, Knowledge Sharing, Altruism

JEL: M10, M19

Received : 16 January 2020

Revised : 28 February 2020

Accepted : 23 March 2020

Type $\quad$ : Research

a Res. Asst., Duzce University, School of Business Administration, Duzce, Turkiye, oguzdemirel@duzce.edu.tr (ORCID ID: 00000003-1436-860X)

b Lecturer, Duzce University, Gumusova Vocational High School, Duzce, Turkiye, onderulu@duzce.edu.tr (ORCID ID: 0000-00030087-4202) 


\section{Giriş}

Bilgi insanlığın hayatını sürdürmesi için gerekli olan en önemli unsurların başında gelmektedir. Gündelik hayattan iş yaşamına, felsefeden bilime kadar her alanda bilgi bulunmaktadır. Örgütler için de bilgi, son yıllarda temel stratejik kaynak haline gelmiştir. Rekabet güçlerini korumak için örgütler geçmişe kıyasla daha çok bilgi üretmek zorunda kalmaktadırlar. Söz konusu bilginin üretimi iki yolla olmaktadır: birinci yol örgütlerin dış çevresinde var olan bilgiyi yakalayıp iş süreçlerine ve ürünlerine aktarmak, ikinci yol ise çalışanlarının sahip olduğu bilgiyi örgüt içinde yayarak örgütsel bilgi hale gelmesini sağlamaktır. İşte, örgüt bünyesindeki bireylerin bilgilerinin örgüt içinde yayılımına yol açan husus, bireylerin bilgi paylaşma davranışlarıdır.

Esasında örgütlerin en önemli bilgi kaynaklarından biri insandır. Zira insan unsuru, gerçekte bilgiyi yaratan, paylaşan ve kullanan varlıktır. Bireylerin bilgi birikimlerini örgüt içindeki bireylerle paylaşmaları, örgütün bir bütün olarak bilgi birikiminin artmasını sağlamaktadır (Ipe, 2003). Buradan hareketle, bireylerin sahip oldukları bilgileri paylaşma davranışlarııın altında yatan nedenleri araştırmak, onları söz konusu davranışı gösterme konusunda teşvik etmeye; böylece örgütlerin bilgi birikimlerinin artmasına yardımcı olacaktır.

Literatür incelendiğinde, bilgi paylaşma davranışının altında yatan etmenlerin birçok farklı açıdan ele alındığı fark edilmektedir. Buna göre bilgi paylaşma davranışının çalışan motivasyonu (Nguyen, Nham, Froese ve Malik, 2019), etik ve dönüşümcü liderlik (Mittal ve Dhar, 2015; Bavik, Tang, Shao ve Lam, 2018), güven (Curado ve Vieira, 2019), örgütsel bağlılık (Curtis ve Taylor, 2018) kavramları ile nasıl bir ilişki içerisinde olduğu gerek teorik gerekse ampirik çalışmalar yoluyla ortaya konmuştur. Türkçe literatür incelendiğinde de bilgi paylaşma davranışının çeşitli bireysel ve örgütsel faktörler ile olan ilişkisinin irdelendiği görülmektedir (Demirel ve Ulu, 2019). Bu kapsamda örneğin Yeniçeri ve Demirel (2007), örgüt içi bilgi paylaşımına yönelik örgütsel ve bireysel engelleri inceleyen bir araştırma yapmışlardır. Çetin ve Şentürk (2016), Türkiye'de çalışan dermatologlar üzerinde yaptıkları araştırmada, bilgi paylaşma davranışını planlı davranış teorisi ve sosyal değişim teorisi bağlamında incelemişlerdir. Eser ve Ensari (2016), yöneticilerin bilgi paylaşma davranışının çalışanların değersiz olma kaygısı üzerinde nasıl bir etkisi olduğunu ve bu etkiye algılanan örgütsel desteğin aracı bir değişken olarak hangi düzeyde tesir ettiğini özel sektör ve kamuda çalışan 217 kişi üzerinde yürüttükleri çalışmada ele almışlardır.

Bahse konu bilimsel araştırmalar göz önünde tutulursa, örgütteki bireylerin bilgi paylaşma davranışlarının, örgütsel özdeşleşme düzeyleri ve özgecilik ile etkileşiminin nasıl ve hangi düzeyde olduğu sorusunun üzerinde yeterince durulmadığı anlaşılmaktadır. Oysaki örgütsel özdeşleşme, "çalışan ile örgüt arasındaki bağı ifade eden bir psikolojik durum" olduğundan, iş yerindeki birçok davranışın açıklayıcısı olabilmektedir (Edwards, 2005: 207). Benzer şekilde, çalışanların örgütün görev ve sorunları ile ilgili gönüllü olarak başkalarının faydasına olacak eylemlerde bulunma eğilimi olarak ifade edilen (Podsakoff, MacKenzie, Moorman ve Fetter, 1991) özgecilik kavramının da bireylerin bilgi paylaşma gibi iş yeri davranışlarının açıklanmasında dikkate alınması gereken bir unsur olduğu düşünülmektedir.

Bu hususlardan hareketle, bu araştırmanın amacı bireylerin örgütsel özdeşleşme düzeyleri ile bilgi paylaşma davranışları arasında bir ilişki olup olmadığını, eğer böyle bir ilişki var ise özgeciliğin bahse konu ilişkide aracılık rolünün bulunup bulunmadığını incelemektir.

Çalışma toplam altı bölümden oluşmaktadır. İkinci bölümde araştırmanın değişkenlerine ait literatür bulunmaktadır. Üçüncü bölümde, hipotezlerin kavramsal arka planı; dördüncü bölümde ise araştırmanın yöntemi yer almaktadır. Beşinci bölümde, hipotezlerin testine ilişkin bulgular mevcuttur. Son bölümde ise bulgular tartışılmış, sonuç ve önerilere yer verilmiştir.

\section{Literatür}

Bu bölümde, araştırmanın temel kavramsal yapıları olan örgütsel özdeşleşme, özgecilik ve bilgi paylaşma davranışı ile ilgili literatür incelemesi sunulmuştur. 


\section{1. Örgütsel Özdeşleşme}

Örgütsel özdeşleşme, bilişsel bir durum olup bireyin kendi değerleri ile içerisinde bulunduğu örgütün değerlerinin birbiriyle özdeşleştiğine yönelik algısıdır (Riketta, 2005). Reade'ye (2001) göre örgütsel özdeşleşme, çalışanın örgütüyle arasındaki psikolojik bir bağı ifade etmekte olup söz konusu bağın sağlamlığı birey ile örgütün değerlerinin birbiriyle benzeşmesinden kaynaklanmaktadır. Bireyler örgütün hedef ve değerlerini kendi hedef ve değerleri gibi kabul etmekte ve neticede bir ölçüde örgüte bağlılık durumu oluşmaktadır (Edwards, 2005: 210).

Örgütsel özdeşlemenin temelinde, esas olarak sosyal kimlik teorisi yer almaktadır. Sosyal kimlik teorisine göre bireyler kendilerini, ait oldukları yapıların özellikleri aracılığıyla tanımlamaktadır. Özdeşleşmeyi de içeren sosyal kimlik teorisi, bireylerin ait olduklarını hissettikleri grup ve yapıların geleceğini kendi geleceğiyle özdeş hale getirdiğini ileri sürmektedir (Ashforth ve Mael, 1989). Kendini örgüt ile özdeş hale getiren ve örgütün özellikleri üzerinden tanımlayan birey, kendisi açısından zor olsa da örgütün başarıya ulaşması için gereken davranışı göstereceği düşünülmektedir (Carmeli, Gilat ve Waldman, 2007).

Esasında psikolojik ve zihinsel bir unsur olan örgütsel özdeşleşme, birbirinden farklı pek çok etmen tarafından etkilenmektedir. Bu etmenlerin önemli bir kısmı örgütsel düzeydeki unsurlar olarak karşımıza çıkmaktadır. Nitekim, bir örgütteki bireylerin özdeşleşme düzeyleri, bahse konu bireylerin örgütün dış dünyadaki prestiji hakkındaki algısından etkilenmektedir; bir başka ifade ile, bünyesinde bulundukları örgütün dış dünyada yüksek prestije sahip olduğunu algılayan bireyler, kendilerini örgütleri ile daha çok özdeşleştirmektedir (Smidts, Pruyn ve Van Riel, 2001).

Örgütsel özdeşleşme, çalışanların iş yerindeki davranış ve performansları üzerinde etkili olan bir faktördür. Turunç ve Çelik'in (2010) savunma sanayiinde çalışanları dahil ettikleri araştırma bulgularına göre, örgütsel özdeşleşme düzeyi yüksek olan çalışanların iş performansı da yüksek olmaktadır. Sağlık sektöründe yürütülen bir çalışmanın neticesinde Tokgöz ve Seymen (2013), örgütsel özdeşlemenin örgütsel güven ve örgütsel vatandaşlık davranışı arasındaki ilişkide aracılık rolü üstlendiğini tespit etmişlerdir; diğer bir ifade ile örgütüne güvenen bireyler kendisini onunla özdeşleştirmekte ve bu özleşme neticesinde çalışanlar örgütsel vatandaşıık davranışı sergilemektedir.

\section{2. Özgecilik}

Literatürde "özgeci yardım (altrustic helping)" olarak da adlandırılan özgecilik, herhangi bir karşılık beklemeden, başkalarının yararına olacak davranışlar sergilemek olarak tanımlanan bir kavramdır (Oswald, 1996: 615). Örgütsel açıdan bakıldığında, Podsakoff ve diğerleri (1990:115) özgeciliği, "örgütsel bir problem veya görevle ilgili başka bir bireye yardım etmeyi içeren isteğe bağlı davranışlar" şeklinde tanımlamaktadır. Aynı zamanda, kendinden önce başkasını düşünmek olarak da ifade edilen özgecilik, kendi zararına bile olsa başkalarının faydasına olacak işler yapmak anlamına gelmektedir (Cropanzano ve Mitchell, 2005: 879).

Özgecilik birey düzeyinde oldukça farklı unsurlardan etkilenmektedir. Nitekim Kee-Lee'ye (1998) göre, bireylerin kendinden başkalarını düşünme eğilimleri yaş gruplarına göre farklılık göstermekte olup kişilerin yaşları ilerledikçe özgecilik kaynaklı davranış eğilimlerinin yükseldiği gözlemlenmiştir. Bir başka çalışmada Oswald (1996), başkalarının duygularını anlama kabiliyeti yüksek olan bireylerin özgecilik düzeylerinin de yüksek olduğunu ortaya çıkarmıştır.

\subsection{Bilgi Paylaşma Davranışı}

Bilgi paylaşma davranışı, bireyin sahip olduğu bilgiyi, örgütteki diğer bireylerin de kullanabileceği hale getirmesi eylemi olarak ifade edilmektedir. Bireyler arasındaki bu bilgi paylaşımı, bir tarafın elinde bulundurduğu bilgiyi, kendisi dışındaki bireylerin anlayabilmesi, özümseyebilmesi ve kullanabilmesi için uygun biçime dönüştürme faaliyetini içermektedir (Ipe, 2003). Cummings (2004) ise bilgi paylaşımını, prosedürlerin uygulanması, yeni fikirlerin geliştirilmesi ve problemlerin çözülmesi için işbirliğinin sağlanabilmesi amacıyla bilginin diğer bireylere tedarik edilmesi süreci olarak tanımlamıştır. Bilginin bireyler arasında paylaşımı yazılı olabileceği gibi yüz yüze iletişim neticesinde de gerçekleşebilir (Wang ve Noe, 2010). 
Bilgi paylaşma davranışının örgütlere sağladığı en önemli katkı, örgüt içerisindeki hem bireyler hem de takımlar arasında bilgi transferine imkân vermesidir. Bireylerde bulunan örtük bilgiler örgütler için ciddi bir bilgi kaynağı olduğundan (Argote ve Ingram, 2000) söz konusu bilgilerin bireyden bireye aktarımı neticesinde örgütsel bilgi dağarcı̆̆ı da gelişmektedir. Bilgi temelli firma teorileri de bünyesindeki bireylerde bulunan bilgileri başarılı bir biçimde birbiri ile entegre edebilen firmaların pazarda rakiplerinin önünde olduğunu ileri sürmektedir (Sabherwal ve Becerra-Fernandez, 2003).

\section{Hipotezlerin Kavramsal Arka Planı}

Bu araştırmada, örgütsel özdeşleşmenin bilgi paylaşma davranışına olan etkisinde özgeciliğin aracılık rolü ele alınmıştır. Çalışma kapsamında ortaya atılan örgütsel özdeşleşme ve bilgi paylaşma davranışı ilişkisi, örgütsel özdeşleşme ve özgecilik ilişkisi ve nihayet özgecilik ile bilgi paylaşma davranışı arasındaki ilişki hipotezlerinin kavramsal arka planına dair literatür incelemesi gerçekleştirilmiş ve kavramsal kurgu yapılmıştır.

\section{1. Örgütsel Özdeşleşme ve Bilgi Paylaşma Davranışı İlişkisi}

Örgütsel özdeşleşme kavramı, iş yerindeki birçok çalışan davranışının açıklanmasında kullanılan bir unsurdur (Riketta, 2005). Bireylerin örgütleri ile arasındaki psikolojik bağın neticesi olarak ifade edildiğinden, örgütsel özdeşlemenin çalışan düzeyde farklı çıktılarının olabileceği savunulmaktadır (Edwards, 2005). Bu çıktılardan biri de bireylerin bilgi paylaşma davranışıdır. Alan yazını incelendiğinde, örgütsel özdeşleşmenin bilgi paylaşma davranışını olumlu yönde etkilediğini gösteren çalışmaların mevcut olduğu görülmektedir. Nitekim, Carmeli, Atwater ve Levi (2011), örgütsel özdeşleşme ile bilgi paylaşma davranışı arasında pozitif bir etkileşimin olduğunu, örgütsel özdeşleşmenin yükselmesi halinde çalışanların bilgi paylaşma düzeylerinin de yükseldiğini belirtmektedir. Bao, Xu ve Zhang (2016), Çin'de faaliyet gösteren 50 işletme üzerinde yürüttükleri kapsamlı araştırmalarında, örgütsel özdeşleşmenin bilgi paylaşma davranışı üzerinde olumlu bir etkisi olduğunu ortaya koymuşlardır. Benzer şekilde Xiao, Liu ve Zhou (2018), örneklemini 228 çalışanın oluşturduğu çalışmalarında özdeşleşmenin bilgi paylaşma üzerinde pozitif bir tesiri olduğunu tespit etmişlerdir. Tüm bu hususlardan yola çıkarak aşağıdaki hipotez oluşturulmuştur.

$\mathbf{H}_{1}$ : Örgütsel özdeşleşmenin bilgi paylaşma davranışı üzerinde olumlu bir etkisi vardır.

\section{2. Örgütsel Özdeşleşme ve Özgecilik iliş̧kisi}

Örgütsel özdeşleşmenin özgecilik kavramı ile olan ilişkisi, literatürde örgütsel vatandaşlık kavramı üzerinden kurgulanmaktadır. Bu durumun ana sebebi, örgütsel davranış literatüründe özgeciliğin esasında örgütsel vatandaşlık davranışının bir bileşeni olarak ele alınmasıdır (Smith, Organ ve Near, 1983).

Kendilerini örgütleri ile özdeşleştiren bireylerin, diğer bir ifade ile kendi başarısını içinde bulunduğu örgütün başarısı ile bir tutan kişilerin, örgütün görev ve sorunları ile ilgili durumlarda gönüllülük esasına dayanarak ve herhangi bir karşılık beklentisi içerisinde olmadan davranış göstermektedir. Karabey ve İş̧an (2007), 83 özel sektör çalışanı üzerinde yürüttükleri araştırma neticesinde örgütsel özdeşleşmenin örgütsel vatandaşığın unsurlarından biri olarak alınan özgecilik üzerinde pozitif bir etkisi olduğunu tespit etmiştir. Benzer şekilde, kamu sektöründe gerçekleştirilen bir araştırmada Tokgöz ve Seymen (2013), çalışanların örgütsel özdeşleşme düzeyleri yükseldikçe özgecilik seviyelerinin de arttığını ortaya koymuştur. Ek olarak, Shim ve Faerman (2017) da kamu çalışanlarında örgütsel özdeşleşmenin özgecilik üzerinde olumlu ve anlamlı bir tesiri olduğunu ortaya çıkarmışlardır. Tüm bu hususlardan hareketle, aşağıdaki hipotez oluşturulmuştur.

$\mathbf{H}_{2}$ : Örgütsel özdeşleşmenin özgecilik üzerinde olumlu bir etkisi vardır.

\section{3. Özgecilik ve Bilgi Paylaşma Davranışı iliş̧kisi}

Özgecilik örgütle ilgili hususlarda, hiçbir karşılık beklemeden, başkalarının yararına olacak gönüllü davranışlar sergilemek olarak tanımlanmıştır (Podsakoff vd., 1990; Oswald, 1996). Bu kapsamda, eğer çalışanlar yüksek bir özgecilik düzeyine sahipse, örgütün süreçleriyle ilgili veya örgütün işine yarayabilecek bilgileri iş arkadaşlarıyla paylaşma konusunda gönüllü olacakları düşünülmektedir (Dekas, Bauer, Welle, 
Kurkoski ve Sullivan, 2013). Nitekim literatürde, bu görüşü destekleyen çalışmalar mevcuttur. Örneğin Lin (2008), Tayvan'daki çeşitli kurumlarda profesyonel olarak çalışan ve aynı zamanda yönetim bilişim sistemleri yüksek lisansı yapan bireyler üzerinde yaptığı araştırma neticesinde özgeciliğin bilgi paylaşma davranışını olumlu etkilediğini belirtmektedir. Ramasamy ve Thamaraiselvan (2011), 181 kişi üzerinde yaptıkları çalışma sonucunda bireylerin özgecilik düzeylerinin yükseldiği durumda bilgi paylaşma davranışlarının da arttığını tespit etmişlerdir. Tuan (2017), kamu çalışanları üzerinde yürüttüğü araştırmada, özgeciliği örgütsel vatandaşlık davranışı kapsamında ele almış ve bilgi paylaşma davranışı üzerinde olumlu etkisi olduğunu ortaya çıkarmıştır. Bu hususlardan hareketle, özgecilik ile bilgi paylaşma davranışı ilişkisi hakkında aşă̆ıdaki hipotez oluşturulmuştur.

$\mathbf{H}_{3}$ : Özgeciliğin bilgi paylaşma davranışı üzerinde olumlu bir etkisi vardır.

Yukarıdaki hipotezlere ek olarak, örgütsel özdeşleşmenin bilgi paylaşma davranışı üzerindeki etkisinde özgeciliğin aracılık rolü bulunduğuna dair hipotez geliştirilmiştir. Literatür incelendiğinde, bu rolü araştıran herhangi bir çalışmaya rastlanmamıştır.

$\mathbf{H}_{4}$ : Özgeciliğin, örgütsel özdeşleşmenin bilgi paylaşma davranışı üzerindeki etkisinde aracılık rolü vardır.

Yukarıda bahsedilen hususlardan hareketle oluşturulan araştırma modeli Şekil 1'de yer almaktadır.

Şekil 1. Araştırmanın Modeli

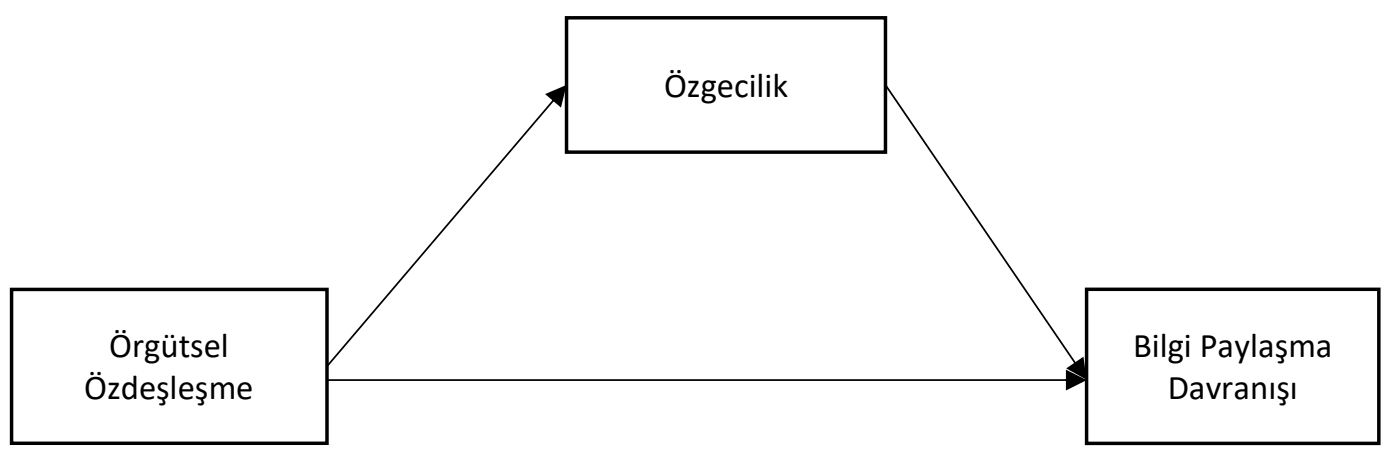

\section{Araştırmanın Yöntemi}

Bu bölümde araştırmanın veri toplama aracı, evren ve örneklemi ile kullanılan veri analiz tekniği hakkında bilgiler verilmektedir.

\subsection{Veri Toplama Aracı}

Araştırma hipotezlerinin sınanmasında kullanılan veriler, Düzce Üniversitesi'nde çalışan akademik ve idari personelden anket yoluyla elde edilmiştir. Ankette yer alan ifadeler asıl olarak ingilizce dilinde türetildiğinden, ifadelerin tümü tekrar-tercüme (back-translation) tekniği ile (Brislin, 1980) Türkçeye çevrilmiştir. Diğer bir anlatımla ankette yer alan ifadeler yazarlardan biri tarafından Türkçeye tercüme edilmiş, diğer yazar da bağımsız bir şekilde Türkçe ifadeleri tekrar İngilizceye çevirmiş ve ifadeler kontrol edilmiştir. Araştırmanın anketi katılımcılara dağıtılmadan önce alanda uzman üç akademisyenle birlikte değerlendirilmiş ve ifadelerin doğru anlaşılmasına engel olabilecek bozukluklar giderilmiştir.

Araştırma verilerinin toplanmasında kullanılan ölçeklerin hepsi literatürde var olan ölçeklerdir, diğer bir anlatımla araştırma için ölçek geliştirme çalışması yapılmamıştır. Ankette yer alan ifadelerin tamamı $5^{\prime}$ li Likert ölçeği kullanılarak ölçülmüştür (1=Kesinlikle Katılmıyorum, 5=Kesinlikle Katılıyorum). Bütün ifadeler için ortalama değerler hesaplanmış ve güvenilirlik düzeylerinin analizi amacıyla Cronbach's Alpha katsayıları kullanılmıştır. Söz konusu katsayıların 0,70'in üzerinde olması halinde ölçeklerin güvenilir olduğu sonucuna ulaşılmıştır (Nunnally, 1978). 
Örgütsel özdeşleşme değişkeninin ölçülmesinde, Mael ve Ashforth (1992) tarafından geliştirilen ve altı ifade içeren ölçek tercih edilmiş ve araştırmaya uyarlanmıştır. Ölçekte yer alan ifadelere örnek olarak, "Birisi çalıştığım üniversiteyi eleştirirse bunu kişisel bir hakaret olarak algılarım" cümlesi verilebilir. Örgütsel özdeşleşme ölçeğinin Cronbach's Alpha güvenilirlik katsayısı 0,78 olarak hesaplanmış olup iyi seviyededir.

Özgecilik değişkeninin ölçülmesinde Podsakoff ve diğerlerinin (1990) çalışmalarında kullandığı örgütsel vatandaşlık davranışı ölçeğinde yer alan ve toplamda dört ifadenin yer aldığı özgecilik ölçeği çalışmaya uyarlanıp kullanılmıştır. Ölçekte yer alan ifadelere örnek olarak, "Işle ilgili problemi olan kişilere yardım etmek için gönüllü olarak kendi zamanımı ayırııı" cümlesi verilebilir. Bahse konu ölçeğin Cronbach's Alpha katsayısı 0,83 olup güvenilirliğinin iyi düzeyde olduğu görülmektedir.

Bilgi paylaşma davranışı değişkenine ait verilerin toplanmasında Chennamaneni, Teng ve Raja'nın (2012) yaptığı çalışmanın ölçeği uyarlanmıştır. Ölçekte toplam dört ifade bulunmakta olup örnek ifadelerden bir tanesi "iş deneyimlerimi çalışma arkadaşlarımla paylaşırım” şeklindedir. Bilgi paylaşma davranışı ölçeğinin

Cronbach's Alpha değeri 0,91 olarak hesaplanmış olup güvenilirlik düzeyinin oldukça iyi bir seviyede olduğu tespit edilmiştir.

Bu ölçeklere ek olarak katılımcıların cinsiyeti, yaşı, çalışma süresi ve kurum içindeki pozisyonunu (akademik-idari) tespit etmeye yönelik sorular sorulmuştur.

\subsection{Evren ve Örneklem}

Araştırmanın evreni, Düzce Üniversitesi'nde görev yapan 1250 akademik ve 750 idari personel olmak üzere toplam 2000 kişiden oluşmaktadır. Tam sayım örnekleme yöntemi kullanılmış, anketler online olarak bütün personellerin e-posta adreslerine gönderilmiştir. Gönderilen bağlantıda araştırmaya katılımın tamamen gönüllü olduğu ve bahse konu anketle toplanan verilerin çalışma dışında hiçbir platformda hiçbir şekilde kullanılmayacağı ve paylaşıımayacağı özellikle vurgulanmıştır. Katılımcıların anketi bir internet sitesi üzerinden yanıtlamaları sağlanmış, bu sayede kimlik bilgilerinin açığa çıkmasının önüne geçilmiştir. Evrende yer alan bireylerden 360 kişi anketi cevaplandırmış olup eksik değerlendirmelerin bulunduğu anketlerin ayıklanma işleminden sonra kalan 345 anket araştırmanın örneklemini oluşturmaktadır. Sekaran ve Bougie (2013), 2000 kişilik bir evren için örneklemin en az 322 katılımcıdan oluşması gerektiğini belirtmektedir. Çalışmanın örneklemi ise 345 kişi olup bahsedilen alt sınırın üzerindedir. Örnekleme ait tanımlayıcı istatistikler Tablo 1'de sunulmuştur.

Tablo 1. Örnekleme Ait Tanımlayıcı İstatistikler

\begin{tabular}{|l|l|c|c|}
\hline \multicolumn{1}{|c|}{ Grup } & \multicolumn{1}{|c|}{ Alt grup } & Frekans & Yüzde (\%) \\
\hline \multirow{4}{*}{ Cinsiyet } & Erkek & 225 & 65,2 \\
\cline { 2 - 4 } & Kadın & 120 & 34,8 \\
\hline \multirow{5}{*}{ Yaş } & 25 'ten Küçük & 4 & 1,2 \\
\cline { 2 - 4 } & $25-30$ Arası & 50 & 14,5 \\
\cline { 2 - 4 } & $31-35$ Arası & 95 & 27,5 \\
\cline { 2 - 4 } & $36-40$ Arası & 97 & 28,1 \\
\cline { 2 - 4 } & 41 ve Üzeri & 99 & 28,7 \\
\hline \multirow{5}{*}{ Çalışma Süresi } & 1 Yıldan Az & 18 & 5,2 \\
\cline { 2 - 4 } & $1-5$ Yıl & 71 & 20,6 \\
\cline { 2 - 4 } & $6-10$ Yıl & 100 & 29 \\
\cline { 2 - 4 } & $11-15$ Yıl & 71 & 20,6 \\
\cline { 2 - 4 } & 16 Yıl ve Üzeri & 85 & 24,6 \\
\hline \multirow{3}{*}{ Pozisyon } & Akademik & 243 & 70,4 \\
\cline { 2 - 4 } & Idari & 102 & 29,6 \\
\hline
\end{tabular}




\subsection{Ortak Yöntem Varyansı}

Sosyal bilimlerde yürütülen araştırmalarda, verilerin tek seferde (cross-sectional) ve aynı kaynaktan toplanması, araştırma sonuçlarında yanlılığa yol açabilmektedir. Bu durum teorik yapılar arasında kurulan modele ilişkin analiz bulgularında hatalara neden olabilmektedir (Podsakoff, MacKenzie, Lee ve Podsakoff, 2003). Bu durumun önüne geçebilmek için, ortak yöntem varyansı kontrol edilmiştir.

Çalışmada ortak yöntem varyansı olup olmadığını ortaya çıkarmak amacıyla, ankette yer alan ifadelerin tek bir yapıya bağlandığı, tek faktörlü doğrulayıcı faktör analizi yapılmıştır. Söz konusu analiz sonuçlarının düşük değerler vermesi halinde ortak yöntem varyansının dikkate değer bir etkisi olmadığı çıkarımı yapılmıştır. Nitekim, analiz bulgularına göre araştırma verilerinde ortak yöntem varyansının olduğuna işaret edebilecek, anlamlı bir tek faktörlü yapı ortaya çıkmamıştır (CMIN/df =6,389 p=0,000; GFI = 0,66; CFI $=0,533$; RMSEA $=0,125)$. Bu bulgu ortak yöntem varyansının dikkate alınması gereken bir etkisi olmadığını ifade etmektedir.

\subsection{Faktör Analizleri}

Araştırma sürecinde elde edilen verilerin araştırma modeline uyup uymadığını sınamak maksadıyla, SPSS paket programı kullanılarak keşfedici faktör analizi, AMOS paket programı kullanılarak doğrulayıcı faktör analizi yapılmıştır.

Örgütsel özdeşleme, özgecilik ve bilgi paylaşma davranışı değişkenleri için keşfedici faktör analizi yapılırken, birincil bileşenler analizi tekniği ve varimax döndürme metodu tercih edilmiş, özdeğeri 1'den yüksek olan faktörlerin seçilmesine karar verilmiştir. Ayrıca, faktör yükü 0,50 ve üzerinde olan ifadeler ölçekte tutulmuştur. Bu doğrultuda yapılan keşfedici faktör analizine ait bulgular Tablo 2'de sunulmuştur.

Tablo 2. Keşfedici Faktör Analizi Bulguları

\begin{tabular}{|c|c|c|c|c|}
\hline Ölçek & ifadeler & $\begin{array}{l}\text { Faktör } \\
\text { Yükleri }\end{array}$ & $\begin{array}{c}\text { KMO } \\
\text { Değeri }\end{array}$ & $\begin{array}{c}\text { Açılklanan } \\
\text { Varyans }\end{array}$ \\
\hline \multirow{6}{*}{$\begin{array}{l}\text { Örgütsel } \\
\text { Özdeşleşme }\end{array}$} & 004: Üniversitemin başarısı benim başarımdır. & 0,795 & \multirow{6}{*}{0,769} & \multirow{6}{*}{49,684} \\
\hline & $\begin{array}{l}\text { O03: Üniversitem hakkında konuştuğumda "onlar" } \\
\text { yerine "biz" kelimesini tercih ederim. }\end{array}$ & 0,728 & & \\
\hline & $\begin{array}{l}\text { O05: Birisi çalıştığım üniversiteyi övdüğünde bunu } \\
\text { kişisel bir iltifat olarak düşünürüm. }\end{array}$ & 0,714 & & \\
\hline & $\begin{array}{l}\text { 001: Birisi çalıştığım üniversiteyi eleştirirse bunu } \\
\text { kişisel bir hakaret olarak algılarım. }\end{array}$ & 0,694 & & \\
\hline & $\begin{array}{l}\text { 006: Medyada üniversitemle ilgili olumsuz bir } \\
\text { haber olursa bundan rahatsızlık duyarım. }\end{array}$ & 0,660 & & \\
\hline & $\begin{array}{l}\text { 002: Diğer insanların çalıştığım üniversite } \\
\text { hakkındaki düşünceleri beni çok ilgilendirir. }\end{array}$ & 0,627 & & \\
\hline \multirow{4}{*}{ Özgecilik } & $\begin{array}{l}\text { OZ3: İşle ilgili problemi olan kişilere yardım etmek } \\
\text { için gönüllü olarak zaman ayırırım. }\end{array}$ & 0,780 & \multirow{4}{*}{0,695} & \multirow{4}{*}{48,580} \\
\hline & $\begin{array}{l}\text { OZ1: Ağır iş yükü olan diğer çalışanlara yardım } \\
\text { ederim. }\end{array}$ & 0,760 & & \\
\hline & OZ2: İşe gelmeyenlerin işlerine yardım ederim. & 0,681 & & \\
\hline & $\begin{array}{l}\text { OZ4: Zorunlu olmasa bile yeni gelen çalışanlara } \\
\text { ortama ve işe uyum sağlamalarına yardımcı olurum. }\end{array}$ & 0,542 & & \\
\hline \multirow{4}{*}{$\begin{array}{l}\text { Bilgi } \\
\text { Paylaşma } \\
\text { Davranışı }\end{array}$} & $\begin{array}{l}\text { BP3: Eğitim öğretimle edindiğim uzmanlığımı } \\
\text { çalışma arkadaşlarımla paylaşırım. }\end{array}$ & 0,936 & \multirow{4}{*}{0,840} & \multirow{4}{*}{80,502} \\
\hline & $\begin{array}{l}\text { BP4: İşle ilgili teorik bilgilerimi çalışma } \\
\text { arkadaşlarımla paylaşırım. }\end{array}$ & 0,915 & & \\
\hline & $\begin{array}{l}\text { BP1: İş deneyimlerimi çalışma arkadaşlarımla } \\
\text { paylaşırım. }\end{array}$ & 0,873 & & \\
\hline & $\begin{array}{l}\text { BP2: Yaptığım işin sırrını ve nasıl yapıldığını çalışma } \\
\text { arkadaşlarımla paylaşııı. }\end{array}$ & 0,863 & & \\
\hline
\end{tabular}


Tablo 2'de de görüldüğü gibi, örgütsel özdeşleşme değişkenine ait ölçeğin keşfedici faktör analizi sonucuna KMO örneklem yeterlilik değeri 0,769 olup açıkladığı varyans \%49,68'tir. Söz konusu ölçekte yer alan altı ifadenin faktör yükleri 0,627 ile 0,795 arasındadır. Özgecilik değişkeninin ölçeğine ait faktör analizi bulgularına göre KMO örneklem yeterlilik değeri 0,695 ve açıklanan varyans $\% 48,58^{\prime}$ tir. Ölçekteki ifadelerin faktör yükleri 0,780 ile 0,542 arasında yer almakta olup hiçbir ifade ölçekten çıkarılmamıştır. Son olarak, bilgi paylaşma davranışı ölçeğinin faktör analizi bulguları incelendiğinde KMO örneklem yeterlilik değerinin 0,840, açıklanan varyansın da \%80,50 olduğu görülmektedir. Bahse konu ölçekteki toplam dört ifadenin tamamının faktör yükleri ise 0,936 ile 0,863 değerleri içerisindedir.

İkinci aşama olan doğrulayıc faktör analizi, örgütsel özdeşleşme, özgecilik ve bilgi paylaşma davranışı olmak üzere üç yapıyı ölçen toplam on dört ifade üzerinde yürütülmüş olup bulgular Tablo 3’te verilmektedir.

Tablo 3. Doğrulayıcı Faktör Analizi Bulguları

\begin{tabular}{lcccccc}
\hline Ölçek & İfade Sayısı & CMIN/df & GFI & IFI & CFI & RMSEA \\
\hline Örgütsel Özdeşleşme & 6 & 2,602 & 0,98 & 0,98 & 0,98 & 0,068 \\
\hline Özgecilik & 4 & 1,632 & 0,99 & 0,99 & 0,99 & 0,043 \\
\hline Bilgi Paylaşma Davranışı & 4 & 1,346 & 0,99 & 0,99 & 0,99 & 0,032 \\
\hline
\end{tabular}

Doğrulayıcı faktör analizinde, CMIN/df değerinin 3'ün altında olması, GFI, IFI ve CFI değerlerinin 0,90 ve üzerinde olması, RMSEA değerinin ise $0,08^{\prime}$ in altında olması, ölçüm modelinin verilere iyi uyum sağladığını göstermektedir (Schumacker ve Lomax, 2010). Tablo 3'te yer alan doğrulayıcı faktör analizi sonuçlarına göre, araştırmada kullanılan ölçüm modeli verilere oldukça iyi uyum sağlamaktadır.

\section{Hipotezlerin Testine İlişkin Bulgular}

Araştırmanın hipotezleri sınanmadan önce değişkenlere ait ortalama, standart sapma ve korelasyon değerleri hesaplanmış ve söz konusu değerler Tablo 4'te verilmiştir.

Tablo 4. Değişkenlerin Ortalama, Standart Sapma, Cronbach's Alpha ve Korelasyon Değerleri

\begin{tabular}{lccccc}
\hline \multicolumn{1}{c}{ Değişkenler } & Ortalama & Std. Sapma & $\mathbf{1}$ & $\mathbf{2}$ & $\mathbf{3}$ \\
\hline 1) Örgütsel Özdeşleşme & 3,65 & 0,69 & $0,78^{\mathrm{a}}$ & & \\
2) Özgecilik & 3,73 & 0,67 & $0,16^{* *}$ & $0,83^{\mathrm{a}}$ & \\
3) Bilgi Paylaşma Davranışı & 4,32 & 0,48 & $0,22^{* *}$ & $0,30^{* *}$ & $0,91^{\mathrm{a}}$ \\
\hline Not: ${ }^{* *} \mathrm{p}<0,01, \mathrm{a}=$ Cronbach's Alpha değerleri & & & &
\end{tabular}

Tablo 4'te yer alan ortalama değerlerine bakıldığında, çalışanların örgütsel özdeşleşme, özgecilik ve bilgi paylaşma davranışı düzeylerinin ortalamanın üstünde olduğu anlaşılmaktadır. Korelasyon değerlerine incelendiğinde ise örgütsel özdeşleşme ve bilgi paylaşma davranışı arasında pozitif yönlü ve anlamlı bir ilişki $(r=0,22, p<0,01)$, örgütsel özdeşleşme ve özgecilik arasında pozitif ve anlamlı doğrusal ilişki $(r=0,16, p<0,01)$ ve özgecilik ile bilgi paylaşma davranışı değişkenleri arasında pozitif yönde anlamlı bir iliş̧i $(r=0,30, p<0,01)$ olduğu görülmektedir.

Araştırma hipotezlerinin test edilmesi sürecinde, öncelikle araştırma modelinde bağımsız değişken olarak yer alan örgütsel özdeşleşmenin bilgi paylaşma davranışı üzerindeki etkisini sınamak maksadıyla regresyon analizi yürütülmüştür. Analiz bulguları Tablo 5'te yer almaktadır.

Tablo 5. Örgütsel Özdeşleşme - Bilgi Paylaşma Davranışı Regresyon Analizi Bulguları

\begin{tabular}{lcccc}
\hline & Katsayı & Std. Hata & $\mathbf{t}$ & $\mathbf{p}$ \\
\hline Sabit & 3,756 & 0,136 & 27,518 & 0,000 \\
OO & 0,154 & 0,037 & 4,217 & 0,000 \\
\hline Bağımlı Değişken = BPD (Bilgi Paylaşma Davranışı) & & \\
Bağımsız Değişken = OO (Örgütsel Özdeşleşme) & & \\
$\mathbf{R}^{2}=0,049$ & $\mathbf{F}=17,781, \mathrm{p}<0,000$ & & \\
\hline
\end{tabular}


Tablo 5'teki bulgular incelendiğinde, örgütsel özdeşleşmenin bilgi paylaşma davranışı üzerinde anlamlı ve olumlu bir etkisi olduğu görülmektedir $(\beta=0,154 ; p<0,01)$. Bu bulgudan hareketle, $\mathbf{H}_{\mathbf{1}}$ hipotezi kabul edilmiştir.

Araştırmanın aracılık hipotezlerinin test edilmesi esnasında Hayes (2013) tarafından geliştirilen ve SPSS programı üzerinde çalışan, en küçük kareler regresyon analizi temelli PROCESS v.3.3 eklentisi kullanılmıştır. Test sonucunda ortaya çıkan bulgular Tablo 6 'da sunulmaktadır.

Tablo 6. Aracılık Testine iliş̧kin Bulgular

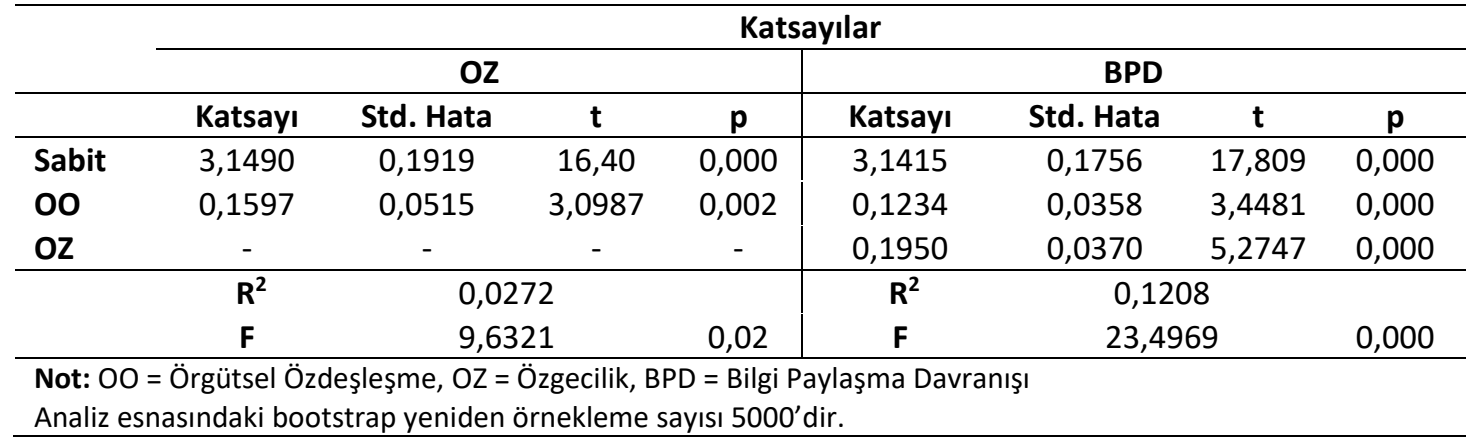

Tablo 6'daki bulgular incelendiğinde, örgütsel özdeşleşme değişkeninin özgecilik değişkeni üzerinde anlamlı ve olumlu etkisi olduğu görülmektedir $(\beta=0,159 ; \boldsymbol{p}<0,01)$. Bu durumda, $\mathbf{H}_{\mathbf{2}}$ hipotezi kabul edilmiştir.

ikinci olarak, özgecilik değişkeninin bilgi paylaşma davranışı üzerinde anlamlı ve olumlu bir etkisi olduğu gözlemlenmektedir $(\beta=0,195 ; p<0,01)$. Buradan hareketle, araştırmanın $\mathbf{H}_{\mathbf{3}}$ hipotezi de kabul edilmiştir.

Son olarak, 5000 bootstrap yeniden örnekleme kullanılarak gerçekleştirilen ve PROCESS eklentisi ile yürütülen aracılık analizinde, aracı değişken olarak modele konan özgeciliğin analize dahil edilmesi ile birlikte, bağımsız değişken olan örgütsel özdeşleşmenin bilgi paylaşma davranışı üzerindeki etkisi anlamsız hale gelmemekte olup $\beta$ katsayısı 0,154'ten (Tablo 5) 0,123'e ( $p<0,01$ ) (Tablo 6) inmiştir. Bir başka deyişle, özgecilik değişkeni ile birlikte yapılan analiz sonucunda örgütsel özdeşleşme değişkeninin katsayısı azalmış ancak bilgi paylaşma davranışı üzerindeki etkisi tam olarak ortadan kalkmamıştır. Baron ve Kenny (1986) bu durumu "kısmi aracılık" olarak nitelendirmektedir. Buradan hareketle, örgütsel özdeşleşmenin bilgi paylaşma davranışı üzerindeki etkisinde özgeciliğin kısmi aracılık etkisi olduğu görülmektedir. Bu doğrultuda, $\mathbf{H}_{4}$ hipotezi kısmen kabul edilmiştir, çünkü özgecilik değişkeninin aracılık rolü tam değil, kısmi bir aracılık etkisidir.

\section{Sonuç ve Öneriler}

Bu araştırma, örgütlerde çalışan bireylerin bilgi paylaşma davranışlarını örgütsel özdeşleşme ve özgecilik aracılı̆ı̆yla açıklamaktır. Araştırmada, bireylerin örgütsel özdeşleşme düzeylerinin bilgi paylaşma davranışları üzerinde etkisi olduğu ve bu etkinin özgecilik aracılığıyla gerçekleştiği savı ortaya atılmıştır.

Araştırmanın bulgularından ilki, örgütsel özdeşleşmenin çalışanların bilgi paylaşma davranışı üzerinde olumlu ve anlamlı bir etkisi olduğunu ortaya koymuştur. Bir kurumda görev alan bireylerin kendilerini o kurumla özdeşleştirmeleri halinde, sahip olduğu bilgi birikimini kurumda görev yapan diğer bireylerle paylaşma düzeyleri daha yüksek olacaktır; çünkü bireyler o kurumun başarılarını kendi başarısı gibi algılamakta, kurumuna yöneltilen övgüleri kendisine yapılmış birer iltifat olarak kabul etmektedir. Bu nedenle bireyin, kurumunun başarılı olması için bilgi paylaşma davranışı gibi örgüt içi davranışları sıklıkla göstermesi doğal olacaktır. Araştırma neticesinde elde edilen bu sonuç, literatürle paralellik göstermektedir. Nitekim, Carmeli vd. (2011), Bao vd. (2016) ve Xiao vd. (2018) yürüttükleri araştırmalarda örgütsel özdeşleşmenin bilgi paylaşma üzerinde pozitif bir tesiri olduğunu tespit etmişlerdir. 
Çalışmanın, "örgütsel özdeşleşmenin özgecilik üzerinde olumlu bir etkisi vardır" hipotezi kabul edilmiştir. Diğer bir ifade ile, bünyesinde bulunduğu örgütüyle özdeşleşme düzeyi yüksek olan çalışanlar, başkalarının yararına olacak davranışları daha çok göstermektedir. Örgüt ile özdeşleşen birey, onun başarısını kendi başarısı gibi kabul edeceğinden, örgütün başarıya ulaşması için gereken gayreti gösterecek ve başkaları yararına olsa bile neticede örgütünün gelişmesine katkı sağlayacağı için örgütteki diğer bireylere yardımcı olacaktır. Bu bulgu, literatürdeki bulgular ile benzerlik göstermektedir. Nitekim Karabey ve İşçan (2007), örgütsel özdeşleşmenin örgütsel vatandaşlı̆ın bir bileşeni olarak alınan özgecilik üzerinde pozitif bir etkisi olduğunu tespit etmiştir. Buna ek olarak, başka çalışmaların (Tokgöz ve Seymen, 2013; Çetinkaya ve Çimenci, 2014; Shim ve Faerman, 2017) bulguları ile de örtüşmektedir.

Araştırmanın bir diğer hipotezi olan "özgeciliğin bilgi paylaşma davranışı üzerinde olumlu bir etkisi vardır" hipotezi de kabul edilmiştir. Özgecilik, örgütle ilgili görev veya problemlerle ilgili başkalarına yardımcı olma anlamına geldiğinden, özgecilik düzeyi yüksek kişilerin aynı örgütte yer alan insanlarla bilgi paylaşma davranışı da daha sık gözlemlenecektir. Bilgi paylaşma davranışı da esasında herhangi bir karşılık beklemeden gösterilen bir davranış türüdür. Bu nedenle, özgecilik düzeyi yüksek kişilerin bilgi paylaşma davranışını daha fazla göstermeleri mümkündür. Söz konusu bulgu, literatürdeki benzer çalışmaların bulguları ile örtüşmektedir. Nitekim Turan (2014), özgeciliğin bilgi paylaşma üzerinde olumlu yönde bir etkisi olduğunu tespit eden bir araştırma yapmıştır. Lin (2008), özgecilik düzeyi yüksek olan çalışanların iş arkadaşları ile daha çok bilgi paylaştı̆̆ını gözlemlemiştir. Benzer şekilde Ramasamy ve Thamaraiselvan (2011) da özgeciliğin bilgi paylaşma davranışı üzerinde pozitif bir tesiri olduğunu belirtmektedir.

Araştırmanın son bulgusu, çalışanların özgecilik seviyesinin, örgütsel özdeşleşmenin bilgi paylaşma davranışı üzerindeki etkisinde kısmi aracılık rolü oynadığını göstermektedir. Bir kurumda görev yapan bireyler kendilerini o kurumla ne kadar çok özdeşleştirirlerse, aynı kurumda çalışan diğer bireylerin de başarılı olması için çalışacak, bunun için sahip olduğu bilgi ve tecrübeyi onlarla paylaşacaktır. Literatürde bu aracılık etkisini gösteren başka bir çalışmaya ulaşılamamıştır. Bu bağlamda, bahse konu etkinin ortaya çıkarılması, yürütülen araştırmanın alan yazınına özgün katkısı olarak değerlendirilmektedir. Çünkü, Demirel ve Ulu'nun (2019) da ortaya koyduğu üzere, özellikle Türkçe bilgi paylaşma literatüründe örgütsel özdeşleşme ve özgecilik kavramlarını, bilgi paylaşma davranışının açıklayıcıları olarak ele alan hiçbir çalışmaya ulaşılamamıştır.

Bilgi, tüm örgütler için hayati öneme sahip bir unsurdur. Üniversitelerin hem bilgi üreten hem de bilgi kullanan kurumlar oldukları düşünüldüğünde, kurum içinde görev yapanların bilgi paylaşma davranışlarının yüksek olması, hem kurumsal işleyişte kullanılan örgütsel bilgi düzeyinin ve üretilen bilimsel bilgi miktarının artmasını sağlayacaktır. Yürütülen araştırma neticesinde, örgütsel özdeşleşmenin çalışanların bilgi paylaşma davranışını özgeciliğin kısmi aracılık etkisi yoluyla arttırdığı tespit edilmiştir. Bu bağlamda üniversitelerde çalışan akademik ve idari personelin bilgi birikimini iş arkadaşları ile paylaşmaları ve bu sayede kurum içi kolektif bilgi birikiminin artması isteniyorsa, çalışanların kendilerini görev yaptıkları kurum ile özdeşleştirmelerini sağlayacak faaliyetlerde bulunmaları önerilmektedir. Bu faaliyetler hayata geçirilirse çalışanlar kendilerini kurumları ile özdeşleştirecek, aynı kurumda görev yaptığı diğer çalışanların işlerini iyi yapmaları için karşılıksız olarak yardımcı olma güdüsü geliştirecek ve böylece sahip olduğu teorik ve pratik bilgi birikimini iş arkadaşlarıyla paylaşarak örgütsel bilgi seviyesinin artmasını sağlayacaklardır.

Her bilimsel araştırmada olduğu gibi, bu çalışmanın da birtakım kısıtları bulunmaktadır. Her şeyden önce araştırma verileri yalnızca bir kamu üniversitesinden elde edilmiştir. Ek olarak, kesikli veri kullanılmış, boylamsal analiz yürütülmemiştir. Bu durum, değişkenler arasında nedensellik ilişkisi kurulmasında zayıflığa yol açmaktadır. Ayrıca araştırma yalnızca nicel araştırma yöntemi kullanılarak gerçekleştirilmiştir.

Bundan sonraki araştırmalarda, çalışmada yer alan değişkenlerin boylamsal modellerle ele alınması önerilmektedir. Ayrıca sonuçlar hakkında genelleme imkânının artabilmesi için, vakıf üniversiteleri ve farkı sektörlerde faaliyet gösteren örgütlerdeki çalışanlar üzerinde araştırma yapılması tavsiye edilmektedir. Buna ek olarak, nitel analizi yöntemleri gibi farklı yöntemler tercih edilerek araştırma konusuna başka bir perspektif getirilebilir. 


\section{Beyan ve Açıklamalar (Disclosure Statements)}

1. Bu çalışmanın yazarları, araştırma ve yayın etiği ilkelerine uyduklarını kabul etmektedirler (The authors of this article are admitted that they complied with the principles of research and publication ethics).

2. Yazarlar tarafından herhangi bir çıkar çatışması beyan edilmemiştir (No potential conflict of interest was reported by the authors).

3. Bu çalışma, intihal tarama programı kullanılarak intihal taramasından geçirilmiştir (This article was screened for potential plagiarism using a plagiarism screening program).

\section{Kaynaklar}

Argote, L., \& Ingram, P. (2000). Knowledge transfer: A basis for competitive advantage in firms. Organizational Behavior and Human Decision Processes, 8(1), 150-169.

Ashforth, B. E., \& Mael, F. (1989). Social identity theory and the organization. Academy of Management Journal, 14(1), 20-39.

Bao, G., Xu, B., \& Zhang, Z. (2016). Employees' trust and their knowledge sharing and integration: The mediating roles of organizational identification and organization-based self-esteem. Knowledge Management Research \& Practice, 14(3), 362-375.

Baron, R. M., \& Kenny, D. A. (1986). The moderator-mediator variable distinction in social psychological research: Conceptual, strategic, and statistical considerations. Journal of Personality and Social Psychology, 51(6), 11731182.

Bavik, Y. L., Tang, P. M., Shao, R., \& Lam, L. W. (2018). Ethical leadership and employee knowledge sharing: Exploring dual-mediation paths. The Leadership Quarterly, 29(2), 322-332.

Brislin, R. W. (1980). Translation and content analysis for oral and written materials. In H.C. Triandis and J.W. Berry (Eds.) Handbook of Cross-Cultural Psychology, 2, 389-444. Boston, MA: Allyn \& Bacon.

Carmeli, A., Gilat, G., \& Waldman, D. A. (2007). The role of perceived organizational performance in organizational identification, adjustment and job performance. Journal of Management Studies, 44(6), 972-992.

Carmeli, A., Atwater, L., \& Levi, A. (2011). How leadership enhances employees' knowledge sharing: The intervening roles of relational and organizational identification. The Journal of Technology Transfer, 36(3), 257-274.

Chennamaneni, A., Teng, J. T., \& Raja, M. K. (2012). A unified model of knowledge sharing behaviours: Theoretical development and empirical test. Behaviour \& Information Technology, 31(11), 1097-1115.

Cropanzano, R., \& Mitchell, M. S. (2005). Social exchange theory: An interdisciplinary review. Journal of Management, 31(6), 874-900.

Cummings, J. N. (2004). Work groups, structural diversity, and knowledge sharing in a global organization. Management Science, 50(3), 352-364.

Curado, C., \& Vieira, S. (2019). Trust, knowledge sharing and organizational commitment in SMEs. Personnel Review, 48(6), 1449-1468.

Curtis, M. B., \& Taylor, E. Z. (2018). Developmental mentoring, affective organizational commitment, and knowledge sharing in public accounting firms. Journal of Knowledge Management, 22(1), 142-161.

Çetin, A., \& Şentürk, M. (2016). Bilgi paylaşma davranışının planlı davranış teorisi ve sosyal değişim teorisi bağlamında incelenmesi: Dermatologlar üzerine ampirik bir araştırma. Ege Akademik Bakış, 16(2), 241-256.

Çetinkaya, M., \& Çimenci, S. (2014). Örgütsel adalet algısının örgütsel vatandaşlık davranışı üzerindeki etkisi ve örgütsel özdeşleşmenin aracııık rolü: Yapısal eşitlik modeli çalışması. Yönetim Bilimleri Dergisi, 12(23), 237-278.

Dekas, K. H., Bauer, T. N., Welle, B., Kurkoski, J., \& Sullivan, S. (2013). Organizational citizenship behavior, version 2.0: A review and qualitative investigation of OCBs for knowledge workers at Google and beyond. Academy of Management Perspectives, 27(3), 219-237.

Demirel, O., \& Ulu, Ö. (2019). Bilgi paylaşma davranışına ait yerli literatürün içerik analizi yöntemiyle incelenmesi. 7. Örgütsel Davranış Kongresi, Burdur, 1431-1439.

Edwards, M. R. (2005). Organizational identification: A conceptual and operational review. International Journal of Management Reviews, 7(4), 207-230. 
Eser, G., \& Ensari, M. Ş. (2016). Yöneticinin bilgi paylaşım davranışının, çalışanların bilgi paylaşımı sonucu değersiz olma kaygısı üzerindeki etkisi ve algılanan örgütsel desteğin aracı rolü üzerine bir araştırma. Işsletme Araştırmaları Dergisi, 8(2), 134-151.

Hayes, A. F. (2013). Introduction to mediation, moderation, and conditional process analysis: A regression-based approach. New York, NY: Guildford Press.

Ipe, M. (2003). Knowledge sharing in organizations: A conceptual framework. Human Resource Development Review, 2(4), 337-359.

Karabey, C. N., \& İşcan, Ö. F. (2007). Örgütsel özdeşleşme, örgütsel imaj ve örgütsel vatandaşlık davranışı ilişkisi: Bir uygulama. Atatürk Üniversitesi Iktisadi ve Idari Bilimler Fakültesi Dergisi, 21(2), 231-241.

Kee-Lee, C. (1998). Effects of age, gender, and participation in volunteer activities on the altruistic behavior of Chinese adolescents. The Journal of Genetic Psychology, 159(2), 195-201.

Lin, C. P. (2008). Clarifying the relationship between organizational citizenship behaviors, gender, and knowledge sharing in workplace organizations in Taiwan. Journal of Business and Psychology, 22, 241-250.

Mael, F., \& Ashforth, B. E. (1992). Alumni and their alma mater: A partial test of the reformulated model of organizational identification. Journal of Organizational Behavior, 13, 103-123.

Mittal, S., \& Dhar, R. (2015). Transformational leadership and employee creativity: Mediating role of creative selfefficacy and moderating role of knowledge sharing. Management Decision, 53(5), 894-910.

Nguyen, T. M., Nham, T. P., Froese, F. J., \& Malik, A. (2019). Motivation and knowledge sharing: A meta-analysis of main and moderating effects. Journal of Knowledge Management, 23(5), 998-1016.

Nunnally, J. (1978). Psychometric methods (2nd Edition). New York: McGraw-Hill.

Oswald, P. A. (1996). The effects of cognitive and affective perspective taking on empathic concern and altruistic helping. The Journal of Social Psychology, 36(5), 613-623.

Podsakoff, P. M., MacKenzie, S. B., Moorman, R. H., \& Fetter, R. (1990). Transformational leader behaviors and their effects on followers' trust in leader, satisfaction, and organizational citizenship behaviors. Leadership Quarterly, $1(2), 107-142$.

Podsakoff, P. M., MacKenzie, S. B., Lee, J. Y. \& Podsakoff, N. P. (2003). Common method biases in behavioral research: A critical review of the literature and recommended remedies. Journal of Applied Psychology, 88, 879-903.

Ramasamy, M., \& Thamaraiselvan, N. (2011). Knowledge sharing and organizational citizenship behavior. Knowledge and Process Management, 18(4), 278-284.

Reade, C. (2001). Antecedents of organizational identification in multinational corporations: Fostering psychological attachment to the local subsidiary and the global organization. Journal of Human Resource Management, 12(8), 1269-1291.

Riketta, M. (2005). Organizational identification: A meta-analysis. Journal of Vocational Behavior, 66, 358-384.

Sabherwal, R., \& Becerra-Fernandez, I. (2003). An empirical study of the effect of knowledge management processes at individual, group, and organizational levels. Decision Sciences, 34(2), 225-260.

Schumacker, R. E., \& Lomax, R. G. (2010). A beginner's guide to structrual equation modeling (3rd Edition). New York: Routledge.

Sekaran, U., \& Bougie, R. (2013). Research methods for business: A skill building approach (6th Edition). UK: Wiley \& Sons.

Shim, D. C., \& Faerman, S. (2017). Government employees' organizational citizenship behavior: The impacts of public service motivation, organizational identification, and subjective OCB norms. International Public Management Journal, 20(4), 531-559.

Smidts, A., Pruyn, A. T. H., \& Van Riel, C. B. M. (2001). The impact of employee communication and perceived external prestige on organizational identification. Academy of Management Journal, 49(5), 1051-1062.

Smith, C. A., Organ, D. W., \& Near, J. P. (1983). Organizational citizenship behavior: Its nature and antecedents. Journal of Applied Psychology, 68(4), 653-663.

Tokgöz, E., \& Seymen, O. A. (2013). Örgütsel güven, örgütsel özdeşleşme ve örgütsel vatandaşlık davranışı arasındaki ilişki: Bir devlet hastanesinde araştırma. Öneri Dergisi, 10(39), 61-76.

Tuan, L. T. (2017). Knowledge sharing in public organizations: The roles of servant leadership and organizational citizenship behavior. International Journal of Public Administration, 40(4), 361-373. 
Turan, A. (2014). Sosyal sermayenin bilgi paylaşma tutumuna etkisinde motivasyonun rolü: Telekomünikasyon sektöründe bir araştırma. İstanbul Üniversitesi Işletme Fakültesi İşletme Iktisadı Enstitüsü Yönetim Dergisi, 25(76), 1-36.

Turunç, Ö., \& Çelik, M. (2010). Çalışanların algıladıkları örgütsel destek ve iş stresinin örgütsel özdeşleşme ve iş performansına etkisi. Yönetim ve Ekonomi, 17(2), 183-206.

Wang, S., \& Noe, R. A. (2010). Knowledge sharing: A review and directions for future research. Human Resource Management Review, 20, 115-131.

Xiao, X., Liu, F., \& Zhou, F. (2018). Narcissistic leadership and employees' knowledge sharing: Influence of organizational identification and collectivism. Social Behavior and Personality, 46(8), 1317-1330.

Yeniçeri, Ö., \& Demirel, Y. (2007). Örgüt içi bilgi paylaşımına yönelik bireysel ve örgütsel engeller üzerine bir araştırma. Selçuk Üniversitesi Karaman iiBF Dergisi, 12(9), 221-234. 
This Page Intentionally Left Blank 